ROCZNIKI NAUK PRAWNYCH

Volume XXVIII, number 3-2018

E n g $1 \mathrm{is} \mathrm{h} \quad \mathrm{v}$ e r s i o

DOI: http://dx.doi.org/10.18290/rnp.2018.28.3-5en

EWA KRUK

\title{
PENAL ORDER PROCEEDINGS \\ AS A MANIFESTATION OF PERMISSIBLE SIMPLIFICATION OF CERTAIN PROCEDURAL INSTITUTIONS
}

\section{PRELIMINARY REMARKS}

The subject matter of criminal proceedings is the issue of the criminal liability of an accused person. Adjudication on this liability is the exclusive domain of common courts and, in cases provided for by statue, also of the Supreme Court. This falls in the broad domain of administration of justice, as provided for in Article 175 para. 1 of the Constitution of the Republic of Poland. ${ }^{1}$ The right to trial is also guaranteed by Article 45 of the Basic Law, which guarantees everyone the right to a "fair and public hearing of his case without undue delay." The same constitutional norm also contains a guarantee that the case will be heard by a "competent, impartial and independent court;" it does not, however, provide any other indication as to the details of the proceedings with regard to the liability indicated here initially. These aspects, as being too specific, were not reflected in the Constitution-which in terms of procedure merely indicates the two-instance structure of the procedure (Article 176 para. 1) - while in other matters related to the organisation and jurisdiction of courts as well as the very proceedings before courts make reference to laws ("they specify laws"). The model of criminal proceedings is determined by the provisions of the Code of Criminal Procedure, ${ }^{2}$ and it is

Ewa KrUK, PhD, Hab, is an assistant professor at the Department of Criminal Procedure, Institute of Criminal Law, Faculty of Law and Administration of Maria Curie-Sklodowska University in Lublin (UMCS); address: Marii Curie-Skłodowskiej 5, 20-031 Lublin, Poland; e-mail: ewa.kruk@poczta.umcs.lublin.pl; https://orcid.org/0000-0003-1976-9330.

${ }^{1}$ Constitution of the Republic of Poland of 2 April of 2 April 1997, Journal of Laws No. 78, item 483 as amended.

${ }^{2}$ Act of 6 June 1997 - The Code of Criminal Procedure, Journal of Laws of 2017, item 1904 as amended [henceforth abbreviated as CCP]. 
their normative nature and the subject matter of the trial that the model applied in ordinary proceedings is based on. It is assumed that ordinary proceedings are typical for autonomous proceedings. ${ }^{3}$ Sometimes, however, in the course of such proceedings it is necessary to modify the degree of procedural formalism. ${ }^{4}$ Modified proceedings, in relation to an ordinary trial regarded as typical, ${ }^{5}$ are referred to as special proceedings because they differ from a trial deemed typical in a given criminal-procedural ${ }^{6}$ system in a manner predetermined by the legislator. The legislature, guided by the specific nature of special proceedings, imposes restrictions on certain guarantees of the participants, without, however, compromising their substance. Such a restriction is exemplified by the penal order procedure, for which the assumption is made that the exercise of the procedure in its entirety in minor cases is not always necessary to achieve the objectives of criminal proceedings set out in Article $2 \S 1$ of the Polish Code of Criminal Procedure.

\section{REASONS FOR THE DIVERSITY OF COURT PROCEDURES}

Having a very broad legitimisation, ${ }^{7}$ the legislator makes a distinction between ordinary and special procedures in CCP. Ordinary proceedings are governed by Section 8 whereas special proceedings are addressed by Section 10 of the Code. In the initial period of the application of the said normative act, Section 10 regulated the following types of procedure: simplified (Article 468-84), in cases based on private accusation (Article 485-99), penal order proceedings (Articles 500-7) and proceedings related to minor offences (Articles 508-17). In 2007, a new accelerated procedure was added (Articles

\footnotetext{
${ }^{3}$ J. SKORUPKA, "Rozdział II. Pojęcie procesu karnego. Przedmiot i podstawa procesu," in System prawa karnego procesowego. Zagadnienia ogólne, ed. P. Hofmański (Warszawa: Wydawnictwo LexisNexis, 2013), 1/1: 109.

${ }^{4}$ Ibid.

${ }^{5}$ K. Marszae, S. Stachowiak, and K. ZgryzeK, Proces karny (Katowice: Wydawnictwo Volumen, 2003), 564.

${ }^{6} \mathrm{~S}$. Waltoś, Postępowania szczególne w procesie karnym. Postępowanie kodeksowe (Warszawa: Wydawnictwo Prawnicze, 1973), 7, 11.

${ }^{7}$ The activity of the legislator must, however, take into account the entirety of constitutional provisions, which was reflected in the inconsistency of the original version of Articles 500ff CCP with Article 42 para. 3 of the Constitution of the Republic of Poland, to the extent that until 2003 the Code permitted rulings on the guilt of an accused person in the form of a "penalty order," while the cited constitutional provision allowed such a ruling to be made solely in the form of a "sentence." This incompatibility also included Article 174 of the Polish Constitution, which governs the passing of "sentences" in the name of the Republic of Poland, rather than other decisions.
} 
$517 \mathrm{a}-17 \mathrm{j}),{ }^{8}$ in 2001 procedure for minor offences was deleted from the act, and in 2015 summary proceedings were deleted, too. ${ }^{9}$ The legislator decided to depart from those solutions applied in ordinary procedure, which constitutes the basis for regulations contained in Section $10 \mathrm{CCP}$, the complexity of which results in procedural steps being more time-consuming. The basic premise accompanying these simplifications of the procedure is to shorten the examination of cases of lesser weight. ${ }^{10}$ Given the reduced social burden of criminal procedure, the public perception of the judiciary is improved since the latter is capable of - at least in theory_dealing with minor cases, quickly and efficiently, without the unnecessary involvement of excessive resources.

Andrzej Światłowski rightly claims that in order for proceedings to be special, the following conditions should be met cumulatively: they should relate to criminal liability, differ significantly from ordinary proceedings, the differences must be normative, and the proceedings are to include a decision on the subject matter of the case. ${ }^{11}$ All these conditions are met by the penal order proceedings. This is so because it is a procedure under which the question of criminal liability is decided upon, and this decision as a clear-cut goal, that is it may include only a conviction; it therefore differs from ordinary procedure, since Article $500 \S 2 \mathrm{CCP}$ prescribes the application of the provisions on ordinary proceedings with modifications provided for in Chapter 53, and finally, on the basis of such proceedings a criminal case is resolved.

\section{REDUCTION OF FORMALISM OF PENAL ORDER PROCEEDINGS}

The proceedings grouped in Section 10, despite their different character, are still the fundamental type of proceedings, that is proceedings which strive to establish the criminal liability of the defendant and answer what penalty should be imposed in a specific case. As under ordinary procedure,

\footnotetext{
${ }^{8}$ Article 2 point 3 of the Act of 16 November 2006 amending the act - The Penal Code and certain other acts, Journal of Laws No. 226, item 1648.

${ }^{9}$ Article 1 point 166 of the Act of 27 September 2013 amending the act-The Code of Criminal Procedure and certain other acts, Journal of Laws item 1247 as amended.

${ }^{10}$ For more on this, see A. ŚwIATŁOWSKI, "Rozdział XVI. Typowy i atypowy przebieg procesu karnego," in System prawa karnego procesowego. Zagadnienia ogólne, ed. P. Hofmański (Warszawa: Wydawnictwo LexisNexis, 2013), 239ff.

${ }^{11}$ IDEM, Jedna czy wiele procedur karnych (Kraków: Arche, 2008), 62.
} 
special proceedings are accompanied by additional proceedings intended to bring decisions on issues incidental, auxiliary or consequential to the subject matter of the proceedings. ${ }^{12}$

Among special proceedings we can find those conducted under both public and private complaint procedures. Penal order proceedings belong to the first group. We need to note the disposition of Article $501 \S 2 \mathrm{CCP}$, which expressly excludes the possibility of issuing a penal order in a case based on a private accusation. This exclusion seems to be a consequence of a certain deficiency of the taking of evidence conducted largely as dictated by a nonprofessional private prosecutor and for fear that the court may deem as undeniable the circumstances and guilt of the defendant based only the evidence adduced by this prosecutor together with the indictment, which does not happen as a rule, unless the securing of this evidence under Article $488 \S$ $1 \mathrm{CCP}$ is at stake. ${ }^{13}$ The prohibition under Article $500 \S 2$ CCP eliminates this risk by forcing the court ruling on a private complaint case to hold a hearing and to hear both parties. This prohibition ceases to apply if a public prosecutor "takes over" a private complaint case to prosecute it ex officio pursuant to Article $60 \S 1 \mathrm{CCP}$, although it seems that in this particular case the court should demonstrate a great deal of caution. I believe that it is not possible to refer a case to penal order sitting when the prosecutor has joined the proceedings already pending on the basis of an aggrieved party's complaint, as this is not the case in which an investigation was conducted, and yet it is a favourable circumstance for the issuance of a penal order sentence (Article $500 \S 1 \mathrm{CCP}$ ). This view of the doctrine is also shared by K. Eichstaedt. ${ }^{14}$

In doctrine, somewhat contrary to the nomenclature adopted in the title of Section 10 CCP, Stanisław Waltoś also regards those proceedings whose objectives are not consistent with the principal objective of the criminal proceedings, including among them, for example, pardon proceedings and proceedings concerning pre-trial detention. ${ }^{15}$ As a result, noting that some proceedings, for example correctional and criminal-fiscal cases, were regulated outside the act of June 6, 1997, he defines those grouped under Section 10 CCP especially "code-like."

\footnotetext{
${ }^{12}$ S. WAltoŚ and P. HofMAŃSKi, Proces karny. Zarys systemu (Warszawa: Wolters Kluwer, 2016), 43-44.

${ }^{13}$ This view is endorsed in K. EICHSTAEDT, Komentarz do art. 501 k.p.k., LEX 2018, accessed July 16, 2018, https://sip.lex.pl/\#/commentary/587688318/567763.

${ }^{14}$ IDEM, Postępowania szczególne w polskim procesie karnym (Warszawa: LexisNexis, 2010), 193ff.

${ }^{15}$ Waltoś and Hofmański, Proces karny, 665.
} 
The most noticeable criterion allowing isolation of a given procedure as special proceedings is the formal criterion-the placement of this type of proceedings within Section 10. A criterion which is more important as it affects the core of the problem is the difference between the legal solutions admitted in the course of particular proceedings but unknown in ordinary proceedings or forming an exception to the rules governing such proceedings. According to Waltoś, the difference between a special procedure and a procedure considered by the legislator as typical must be "significant." Therefore, a small difference will not suffice, because such exceptions to a specific rule are also allowed by provisions regulating the course of ordinary proceedings, which does enable one to question the nature of such proceedings or transforming them into some other procedure (e.g. Article 375 $\S 1$ or Article 387 § 1 CCP).

The doctrine distinguishes three types of special proceedings, the criterion being their relation to ordinary proceedings, which constitutes a point of reference for the analysis of individual procedural solutions. A special procedure may therefore be reduced, extended or equivalent proceedings. ${ }^{1617}$ The formal elements of proceedings can be reduced, extended or made equivalent when the legislator sees redundancy, lack or necessity to modify a certain solution in ordinary proceedings, concluding that due to some additional circumstance concerning either the defendant or the act itself, there is a need to treat them differently, which gives rise to a new type of procedure. This need may be justified by pragmatic or even political considerations. Pragmatism in this case is visible in attempts to create, as it were, a fast track procedure for certain cases which the legislator deems to be less serious or relatively uncomplicated. The special proceedings introduced by the decree of November 16, 1945, provide a dishonourable example of political interference in criminal proceedings. ${ }^{18}$

The distinguishing feature of special procedure that is regulated in Section 10 is its reduction and deformalisation in relation to the standard represented by solutions applicable in ordinary proceedings. The regulation of special proceedings is hardly ever a comprehensive regulation, that is individual chapters of the Section 10 of the Code of Criminal Procedure do not contain provisions reproducing solutions concerning ordinary proceedings

\footnotetext{
${ }^{16}$ Ibid., 666-67.

${ }^{17}$ K. DudKa and H. Paluszkiewicz, Postepowanie karne (Warszawa: Wolters Kluwer, 2017), 602 .

${ }^{18}$ Decree of the Council of Ministers of 16 November 1945 on special proceedings, Journal of Laws No. 31, item 301.
} 
but only those which modify or replace the "ordinary" solutions. Therefore, the application of provisions included in one chapter or another of Section 10 may be slightly more difficult, but unnecessary repetition is avoided in this way. This legislative manoeuvre can is exemplified by Article $500 \S 2$ $\mathrm{CCP}$, which makes reference to "the appropriate application of the provisions on ordinary procedure, unless the provisions of this chapter provide otherwise." Before July 1, 2015, this method of referring to the provisions governing ordinary procedure made it possible to classify a particular special procedure as reduced to the so-called first or second degree special procedure, depending on whether the reference to the provisions governing ordinary procedure was a direct reference or whether it was achieved by means of Article $468 \mathrm{CCP}$, which was repealed on that date, prescribing the application of the provisions on ordinary procedure to the simplified procedure unless the provisions of Chapter $51 \mathrm{CCP}$ provided otherwise. Before July 1 , 2015 , this reference was indirect and allowed order penal proceedings to be regarded as a special second-degree procedure. ${ }^{19}$ The deletion of Article 468 CCP brought the amendment to Article $500 \S 2 \mathrm{CCP}$, which transformed penal order proceedings into special reduced first-degree proceedings.

\section{CONDITIONS FOR PENAL ORDER PROCEEDINGS. DISTINCTIVE FEATURES OF PENAL ORDER PROCEEDINGS}

The reference to the provisions governing ordinary proceedings, made in Article $500 \S 2 \mathrm{CCP}$, is not complete and does not cover matters regulated separately in those proceedings ("do not provide otherwise"). These differences concern: 1) criteria for penal order proceedings, 2) the upper limit on a penal order, 3) the content of a penal order sentence, 4) the issuance of a penal order sentences, the service thereof and of a indictment, 5) legal remedies, and 6) the validity of a penal order. ${ }^{20}$

Penal order proceedings depends on the form in which the pre-trial proceedings were conducted. The provision of Article $500 \S 1$ permits this procedure only in cases which were investigated. In accordance with Article $325 \mathrm{~b} \S 1$ points $1-3 \mathrm{CCP}$, such cases are crimes falling within the jurisdiction of the district court: 1) punishable by a penalty not exceeding 5 years

\footnotetext{
${ }^{19}$ See also the judgement of the Supreme Court of 19 April 2011, file ref. no. II KK 285/10, LEX no. 795773.

${ }^{20}$ K. EichSTAEDT, Komentarz do art. 500 k.p.k
} 
imprisonment; in the case of offences against property only if the value of the object of crime or the damage caused or threatened does not exceed PLN 200,$000 ;{ }^{21}$ 2) provided for in Article 159, Article 254a and $262 \S 2 \mathrm{CCP}$; and 3) provided for in Article $279 \S 1$, Article $286 \S 1-2$ and Article $279 \S 2$ of the Penal Code if the value of the object of crime or damage inflicted or threatened does not exceed PLN 200,000. This criterion will not be fulfilled if an investigation was actually conducted in a case which belongs to the category of cases prosecuted under this investigation (Article 309 points1-5 $\mathrm{CCP}$ ), and the investigation was initiated by mistake or an investigation was carried out in a case related to the investigation. This dependence between the form of pre-trial proceedings and penal order proceedings makes it clear that this special and reduced procedure covers less significant and at the same time quite obvious cases, which is confirmed by another positive criterion of penal order proceedings listed in Article $500 \S \mathrm{CCP}$, namely the absence of doubt as to "the circumstances of the act and the guilt of the accused." A conclusion that no such doubts exist must be based exclusively on evidence gathered during preparatory proceedings, as no additional evidence is heard during the penal order trial. The evidence mentioned in Article 500 $\S 3 \mathrm{CCP}$ is derived entirely from the investigation and has been "collected" within its framework. It is therefore not the court's duty to supplement it but only to analyse it at length and evaluate in depth. Only after these measures have been taken can the court "regard" the state of the case as clarified.

The criterion of the absence of such doubts is quite tightly connected with the criterion of not having to hold a hearing referred to Article $500 \S 1$ CCP. Such a hearing would be necessary if there were even the slightest doubt as to the circumstances of the act and the defendant's guilt. In the doctrine, we can come across the view that occasionally a hearing will seem necessary in the light of reasons of general or specific prevention because a trial fulfils an educational role in relation to the defendant and the rest of society, allowing their legal awareness to be influenced. ${ }^{22}$ In a case which is the subject of penal order proceedings, doubts may not arise in respect of either the fundamental or other circumstances essential for the proper criminal-law assessment of the act

\footnotetext{
${ }^{21}$ Pursuant to Article $325 \mathrm{~b} \S 2 \mathrm{CCP}$, for cases concerning offences referred to in $\S 1$ point 1 thereof, no investigation is conducted into offences referred to in Article 155, Article $156 \S 2$, Article 157a $\S 1$, Article $165 \S 2$, Article 168, Article $174 \S 2$, Article 175, Articles 181-84, Article 186, Article 201, Article $231 \S \S 1$ and 3, Article $240 \S 1$, Article 250a §§ 1-3, Article 265 $\S 3$ and in Chapter 36, excluding Articles 297 and 300, and in Chapter 37 of the Penal Code.

${ }^{22}$ EichSTAEDT, Komentarz do art. 500 k.p.k
} 
in question, including the time of the offence, ${ }^{23}$ or those affecting the sentence. The final assessment whether the circumstances of the offence and the guilt are indisputable is not affected by the defendant's refusal to admit his guilt, as this statement was not treated by the legislator as a positive condition for penal order procedure, and the failure to admit does not constitute a negative condition under Article 501 CCP.

The last of the positive conditions for penal order proceedings is the possibility of imposing a custodial sentence or a fine (Article $500 \S 1$ in fine $\mathrm{CCP}$ ) only in the amount specified in Article $502 \S 1 \mathrm{CCP} .{ }^{24}$ The situation referred to in Article $500 \S 1 \mathrm{CCP}$ is not only one in which this threat stems directly from the provision infringed by the defendant, but also when such a possibility arose as a result of applying the institution of extraordinary commutation. Such a broad interpretation of this condition is supported by the Supreme Court in its judgements of May 17, 2011 ${ }^{25}$ and June 10, 2014. ${ }^{26}$ This view, endorsed by me earlier, ${ }^{27}$ was criticized in the doctrine by Andrzej Gaberle. ${ }^{28}$ This author believes that any derogation from the ordinary administration of penalty in favour of the extraordinary institution provided for by Article $60 \S 6$ point 3 of the Penal Code entails the necessity to refrain from issuing a penal order. With all due respect to that author, such rigour does not seem to have its normative justification in Article $500 \S 1$ $\mathrm{CCP}$, which provides for the possibility of imposing certain penalties without further restriction. The restriction of the catalogue of penalties imposed by a penal order to freedom-related penalties may be considered as a special kind of guarantee for defendants, but also as a kind of incentive to accept them and not to appeal such penalties, as otherwise they may be liable to a full range of penalties provided for in a given provision of the Penal Code.

\footnotetext{
${ }^{23}$ Judgement of the Supreme Court of 7 March 2012, file ref. no. II KK 30/12, Prokuratura i Prawo, insert 6 (2012), item 9.

${ }^{24}$ Provision of Article $502 \S 2$ CCP provides for the possibility of awarding - apart from the penalties specified in $\S 1$ thereof - also a punitive measure, forfeiture or a compensation measure if this is allowed by a special provision. However, Article $502 \S 3 \mathrm{CCP}$ permits a punitive measure only, forfeiture or a compensation measure if conditions for the award of this measure only apply.

${ }^{25}$ Judgement of the Supreme Court of 17 May 2011, file ref. no. III KK 117/11, OSNKW of 2011 , no. 9 , item. 80 .

${ }^{26}$ Judgement of the Supreme Court of 10 June 2014, file ref. no. III KK 129/14, LEX no. 1475170.

${ }^{27}$ E. KRUK, „Postępowanie nakazowe,” in Postępowanie szczególne i odrębne w procesie karnym, ed. K. Dudka (Warszawa: Wolters Kluwer, 2012), 71.

${ }^{28}$ A. Gaberle, Postępowania szczególne w kodeksie postępowania karnego z 1997 r. (Kraków: Kantor Wydawniczy Zakamycze, 1998), 33.
} 
This incentive would perhaps be more complete and effective if penal orders were accompanied by a statement of reasons. Meanwhile, Article $504 \S 2$ $\mathrm{CCP}$ exempts courts from this obligation by making the statement of reasons an optional element of penalty order proceedings.

Article $501 \mathrm{CCP}$, mentioned above, containing negative criteria for an issuance of a penal order, actually specifies cases in which the conduct of penal order proceedings is unjustified because this order is, as it were, the crowning of efforts undertaken in these proceedings. There is no point in undertaking proceedings if they cannot lead to a penal order, the issuance of which is the only effective way of terminating such proceedings. The legislator explicitly relaxes the restrictions of Article 501. As of July 1, 2015, it is possible to issue a penal order for a "person deprived of liberty in this or another case" (point 1 repealed), ${ }^{29}$ however, the ban on penal orders in cases initiated by a private accusation (point 2) is retained as well as in situations where the circumstances referred to in Article $79 \S 1 \mathrm{CCP}$ apply (point 3).

The Article 501 point $1 \mathrm{CCP}$ - which was deleted - was regarded by legal practitioners to be a guarantee which was important for defendants who were deprived of freedom in so far as they would have difficulty challenging the penal order. ${ }^{30}$ Although the rules of raising and applying this objection have not been changed in relation to the period preceding the 2013 amendment, this important guarantee norm has been deleted, perhaps too easily submitting to arguments of procedural economics as that happened clearly to the detriment of the coherence of the system of guarantee norms. The departure from Article 501 point $1 \mathrm{CCP}$ precisely due to the shortness of the period for filing an objection (Article $506 \S \mathrm{CCP}$ ) does not seem to be an adequate solution. Difficulties, if any, in the application of Article 501 point $1 \mathrm{CCP}$ were possible to overcome if the wording were made more precise by saying that the article was about the deprivation of liberty which was in force "on the date of the judgement" and not about any, even temporary, deprivation of liberty before that date. ${ }^{31}$

\footnotetext{
${ }^{29}$ Article 501 point 1 repealed by Article 1 point 172 letter a of the Act of 27 September 2013, Journal of Laws of 2013, item 1247.

${ }^{30}$ See also the obsolete judgement of the Supreme Court of 16 October 2014, file ref. no. III KK 272/14, LEX no. 1539460, and the judgement of 30 March 2015, file ref. no. II KK 22/15, LEX no. 1659230 ,

${ }^{31}$ See, however, the judgement of the Supreme Court of 13 December 2010, file. ref. no. IV KK 294/10, OSNwSK of 2010, no. 1, item 2498, where "the prohibition on issuing a penal order pursuant to Article 501 point $1 \mathrm{CCP}$ is not limited to a person deprived of liberty (in this or another case) at the time of consideration" and it applies "also to a person who at that time is not deprived of liberty but was deprived of it earlier, in the course of relevant proceedings."
} 
Another negative criterion is the occurrence of the circumstances listed in Article $79 \S 1$ CCP. After the 2013 amendment became effective, no penal order may be issued if the defendant is under 18 years of age (point 1), deaf, mute or blind (point 2), when there is a reasonable doubt whether his capacity to recognise the significance of the act or to manage his conduct was disabled or significantly compromised at the time when the act was committed (point 3) or when there is a reasonable doubt whether his mental health allows him to participate in the proceedings or to defend himself in an independent and reasonable manner (point 4). As you can see, the prohibition under Article 501 point $3 \mathrm{CCP}$ meets the criteria of mandatory defence and fulfils a guarantee function in relation to defendants listed in Article $79 \S 1$ $\mathrm{CCP}$. Although I believe that there are never too many guarantee norms, in this case we may ask the question whether this ban is really necessary, since it is in the situation referred to in Article $79 \S 1$ CCP that the defendant's procedural interests are protected by the obligatory defence counsel? Does such a defence not protect the defendant sufficiently against the rashness of penal order proceedings and the court's misinterpretation of the evidence attached to the indictment? If, however, we were to give a negative answer at this point, considering that the guarantee under Article 501 point $3 \mathrm{CCP}$ is necessary, it should be pointed out that it is incomplete anyway as it completely ignores the situation provided for in Article $79 \S 2$ CCP. If the legislator wanted to protect defendants unable to defend themselves, it should consistently extend this cover also to compulsory defence occurring in a situation where the court considers it "necessary" for "other circumstances hindering [that] defence."

Since the rule is that adjudication under penal order procedure occurs at the beginning of judicial proceedings, hence the determination of the age of the defendant (point 1), his state of health (point 2), or the emergence doubts at that very moment as to the sanity of the defendant's tempore criminis (point 3), or his ability to defend himself independently and reasonably (point 4) will effectively block the possibility of examining the case under the provisions contained in Chapter 53. This means that the president of the court will become aware of this information after the formal conditions of the indictment have been verified and will not be able to exercise his authority to refer the case to a court hearing under Article $339 \S 3$ point 7 CCP. He will take such a decision only if he considers that all the positive conditions of Article $500 \S \S 1$ and $3 \mathrm{CCP}$ are met and that no negative condition under Article 501 CCP occurs. In principle, there are no formal contraindi- 
cations that a case should be referred to a penal order session after an application submitted under Article $335 \S 2$ CCP to that court sitting has been rejected, referred pursuant to Article $339 \S 1$ point 3 or 3 s CCP. It is not mandatory to refer a case to a penal order sitting, so this procedure is not invoked in the indictment. It does not belong to the prosecutor to assess the validity of the circumstances of the act and the defendant's guilt. Referral of a case to a penal order sitting, effected by the president of the court, is not binding on this court, who can treat the appraisal of the facts of the case made by the president as null and void.

The court examines a case in a sitting, which is a less formal forum than a hearing. The penal order session itself, prescribed by Article $339 \S 3$ point $7 \mathrm{CCP}$, is also a sitting which is inaccessible to the parties. This is expressly provided for in Article $500 \S 4 \mathrm{CCP}$. This restriction is justifiable given the fact that no taking of evidence is done during this sitting, so there is no room for additional speeches by the parties. This secrecy means that the date of this sitting is not communicated to the parties, which adds speed to the process. While the lack of notification raises no doubts, the exclusion of the openness of the session with respect to the issuance of a penal order may be questionable, especially as this exclusion cannot be explained by the morals clause, state security, public order, protection of private life or important private interest, all mentioned in Article 45 para. 2 of the Constitution of the Republic of Poland. It should be remembered, however, that even before July 1, 2003, "the defendant, his defence counsel, the wronged party and his attorney" had the right to participate in a penal order session, ${ }^{32}$ a practice which quite often led to a standstill in the proceedings and the necessity to adjourn the session in the event when any of the entitled participants failed to appear with good reason. Jan Grajewski, among others, welcomed the change in the way court sessions are to be held, thinking that this manner of adjudication should encourage the court to use the possibilities offered by the amended penal order procedure. ${ }^{33}$ A session under Article $500 \S 4 \mathrm{CCP}$ was not mentioned in Article 95b $§ 2 \mathrm{CCP}$, which means that although this is the venue where the case is examined in terms of its merits, the meeting is held in camera, both externally (Article 95b § 1) and internally (Article 500

\footnotetext{
${ }^{32}$ Art. 1 point 195 letter $\mathrm{c}$ of the Act of 10 January 2003 amending the law-Code of Criminal Procedure, the law-Provisions implementing the Code of Criminal Procedure, the Crown Witness Act, and the act on the protection of classified information, Journal of Laws No. 17, item 155.

${ }^{33}$ J. Grajewski, "Rozdział 53. Postępowanie nakazowe. Komentarz do art. 500 k.p.k.," in Kodeks postępowania karnego. Komentarz, by J. Grajewski, L.K. Paprzycki, and S. Steinborn (Kraków: Kantor Wydawniczy Zakamycze, 2006), 2:225.
} 
$\S 4 \mathrm{CCP}$ ). By way of derogation from Article 95b \& $1 \mathrm{CCP}$, neither the president of the court nor the court may order "otherwise."

The solution provided for in Article $500 \S 4 \mathrm{CCP}$ is therefore tantamount to the possibility of adjudicating in a session provided for in the first sentence of Article $95 \S 1$ CCP. By way of exception to the second sentence of Article $95 \S 1 \mathrm{CCP}$, although it is a "decision given in a sitting," a penal order cannot be delivered during a hearing. This view is supported in the doctrine by both Tomasz Grzegorczyk ${ }^{34}$ and Sławomir Steinborn. ${ }^{35}$ Such a solution is favoured not only by the express wording of Article 500 § $4 \mathrm{CCP}$, which constitutes a lex specialis in relation to the second sentence of Article $95 \S 1$ of CCP, but also due to the reasons underlying penal order procedure. A penal order is one of the few cases in which the law permits the issuance of a sentence at a sitting and the only type of ruling that may be issued in a meeting designated to examine a case under Article $339 \S 3$ point 7 CCP.

A court referendary is not authorised to issue a penal order, who is allowed to adjudicate at a sitting only in cases in the scope permitted by the law, and may adjudicate only in the form of a decision (Article $95 \S 2 \mathrm{CCP}$ ). A penal order is issued by a one-person court, which, in relation to the former penal order, was provided for by Article 500 \& $4 \mathrm{CCP}$, and after the amendment of 2003 this can be ascertained by analysing the content of the general provision, that is Article $30 \S 1 \mathrm{CCP}$. However, it does not appear that in the course of penal order proceedings the situation provided for in fine of that provision may arise, namely that the president of the court could order that a case intended for a penal order session be considered by a court of three judges "due to its complexity or gravity." This would be in stark contrast to the nature of cases considered under penal order procedure and, as I see it, this would be incompatible with the condition for sentencing under procedure specified in Article $500 \S 3 \mathrm{CCP}$, that is "the undoubted nature of the circumstances of the act and defendant's guilt." Since penal order procedure is used to consider cases in which investigation was conducted and the collected material suggests that a hearing is not necessary, we can hardly speak of serious "gravity" of such a case (Article $500 \S 1 \mathrm{CCP}$ ).

A penal order is served on, among others, the accuser and the accused and the latter's defence counsel (Article $505 \mathrm{CCP}$ ). This solution was also in

\footnotetext{
${ }^{34}$ T. GRZEGORCZYK, Kodeks postępowania karnego. Komentarz (Warszawa: Wolters Kluwer, 2008), 295.

${ }^{35}$ S. STEINBORN, Komentarz do art. 95 k.p.k., LEX 2018, accessed July 18, 2019, https://sip.lex.pl /\#/commentary/ 587696264/493704.
} 
force during the period when penal order sittings were held with the participation of the parties. The exceptional character of Article $505 \mathrm{CCP}$, however, consists in the fact that the sentence is served on the defendant together with the indictment, which is a visible deviation from the regulation provided for in Article $338 \S 1 \mathrm{CCP}$, meaning that if only the president of the court, having verified the indictment, deems it necessary to refer the case to a penal order sitting, he will not take a decision under Article 338 § 1 CCP until the case has been examined by the court in that meeting. Failure to effect "an immediate service of the indictment" is criticised in the doctrine by Piotr K. Sowiński, who believes that even a small degree of involvement of the defendant at this stage of the proceedings is difficult to reconcile with the disposition of Article 14 point 3a of the International Covenant on Civil and Political Rights. ${ }^{36}$ This view cannot be accepted because this exception has a temporary nature and the accusation, as a rule, does not generally differ greatly from the charge presented to that party in the proceedings. Given such a structure of the first sentence of Article $505 \mathrm{CCP}$, it seems hardly possible to talk about the person's right to defence, although we may be under the same impression for the fact that he was served two such important documents simultaneously - both the penal order and the indictment. However, this is not the case, because even if the defendant does not accept the content of the penal order and the evaluation of evidence accumulated in the course of investigation, the judicial remedy that he uses against the sentence does not require a detailed examination of any of them and produces cassation effects by the mere fact of its submission, not by invoking any substantive arguments in it (Article $506 \S 1$ in conjunction with $\S 3 \mathrm{CCP}$ ).

A penal order is issued by a one-person court. This penal order, issued in accordance with Article $504 \mathrm{CCP}$ should include the designation of the court and the issuing judge, the date of the order, name and surname and other data specifying the identity of the accused person, a precise description of the act assigned by the court to the defendant indicating the relevant provisions of the Penal Code as well as the amount of the penalty and other necessary decisions. If we compare the requirements related to a penal order handed down in penal order proceedings and ordinary proceedings, we can see that the former does not indicate the "place where the case was examined and where the judgement was issued," which is otherwise provided for in

\footnotetext{
${ }^{36}$ P.K. SOwIŃSKI, Uprawnienia składające się na prawo oskarżonego do obrony. Uwagi na tle czynności organów procesowych oraz oskarżonego (Rzeszów: Wydawnictwo Uniwersytetu Rzeszowskiego, 2012), 98.
} 
Article $413 \S 1 \mathrm{CCP}$ in relation to a final judgement in ordinary proceedings. Under this simplified procedure, the "description and legal qualification of the act which the prosecutor charged the defendant with" is not read out (Article $413 \S 1$ point $4 \mathrm{CCP}$ ), and merely "a precise description of the act attributed by the court to the defendant, with an indication of the relevant provisions of the penal law" (Article $504 \S 1$ point 4 CCP) is given. However, the question of indicating the accused person (Article $504 \S 1$ point 3 and Article $413 \S 1$ point $3 \mathrm{CCP}$ ), as well as the description of the act attributed to the defendant by the court and the decision made (Article $504 \S 1$ points 4 and 5 and Article $413 \S 2$ points 1 and $2 \mathrm{CCP}$ ) were resolved in an almost identical manner in terms of the substance as any simplification in this respect would undermine not only the right of the defence but also the essence of administration of justice. Importantly, the question whether to provide or not a statement of reasons for the judgement (Article $504 \S 2$ $\mathrm{CCP}$ ) is left to the discretion of the court examining the case. Although in most cases penal orders are not accompanied by a justification, the very fact that the court may draw up such a justification without a party requesting that - which is standard in first-instance ordinary proceedings (Article $422 \S$ $1 \mathrm{CCP}^{37}$ ), is a noteworthy circumstance and gives the court the opportunity to bring the defendant round to its own reasons and persuade him or her to submit to the decision so that they can quickly put an end to the proceedings in their own case. From my own observations of court practice, I will conclude that this opportunity is not used frequently enough in cases examined in penal order proceedings or that justifications are prepared in a rather stereotyped and abbreviated form.

Pursuant to the third sentence of Article $505 \mathrm{CCP}$, an instruction is attached to a penal order and an indictment citing relevant provisions of the law, the time and manner of filing an objection, and the consequences of failing to register one, which makes the procedure a lot easier, especially for those defendants who are not assisted by a defence counsel. The objection is filed within a shorter time than the appeal, that is only seven days, which is obvious and permissible if we bear in mind that the content of the objection amounts to a statement of lack of consent to such a judgement by the court (Article $506 \S 1 \mathrm{CCP}$ ). If an objection is filed, the defendant does not need to contest the findings of the court or point out procedural errors to it. That the objection is not based on charges follows from the fact that the defendant

\footnotetext{
${ }^{37}$ See, however, e.g. Art. $114 \S 3$ CCP.
} 
has not been involved actively in the jurisdictional stage of the proceedings hence his little knowledge of the court's activities. The defendant retains the right to withdraw the objection until the commencement of court proceedings at the first, main hearing (Article $506 \S 5 \mathrm{CCP}$ ), whereas an effectively revoked objection or one not submitted within the prescribed time limit causes the penal order to become final and enforceable under the procedure applicable to "ordinary" judgements (Article $507 \mathrm{CCP}$ ). The defendant has a special kind of guarantee that the court will not be guided by the findings underlying the penal order during the examination of a case referred for proceedings due to the loss of its legal validity; this guarantee stems from Article $506 \S 6 \mathrm{CCP}$, providing for "not binding that court [...] with the content of an invalid penal order," and the express exclusion under Article $40 \S 1$ point $9 \mathrm{CCP}$ of a judge who "took part in the issuance of a decision against which an objection was registered" against further decisions in the same case. The prohibition by virtue of Article $506 \S 6 \mathrm{CCP}$ is an important solution, which ensures extra protection for the defendant who is subject to the principle of presumed innocence against any signs of prejudice on the part of the court.

\section{FINAL REMARKS}

To sum up, it should be stated that penal order proceedings undeniably entail a reduction of procedural formalism and a reduction of some legal institutions, but this does not happen to the detriment of the basic rules of criminal case examination. The true fact principle (Article $2 \S 2 \mathrm{CCP}$ ), presumption of innocence (Article $5 \S 1 \mathrm{CCP}$ ), and the principle of objectivity continue to apply in this procedure, although the implementation of the last one may be difficult due to the unilaterality of evidence available to the court at the adjudication stage of the penal order proceedings (Article $4 \mathrm{CCP}$ ). In a lesser degree, the following principles are realised: the adversarial principle and openness of proceedings; however, this should be regarded as the price we need to pay for a quicker conclusion of cases which, by their nature, are minor or less complicated. A departure from these principles is offset to benefit the defendant who in exchange gets a judicial remedy enabling him to have his penal order annulled and revert to criminal proceedings which will be conducted in compliance with extremely elaborate rules, risking a more severe conviction and higher costs to be incurred. 


\title{
BIBLIOGRAPHY
}

\author{
SOURCES OF LAW
}

Dekret Rady Ministrów z dnia 16 listopada 1945 r. o postępowaniu doraźnym [Decree of the Council of Ministers of 16 November 1945 on special proceedings]. Journal of Laws No. 31, item 301 .

Constitution of the Republic of Poland of 2 April of 2 April 1997. Journal of Laws No. 78, item 483 as amended.

Ustawa z dnia 6 czerwca 1997 r. - Kodeks postępowania karnego [Act of 6 June 1997-The Code of Criminal Procedure]. Journal of Laws of 2017, item 1904 as amended

Ustawa z dnia 10 stycznia 2003 r. o zmianie ustawy - Kodeks postępowania karnego, ustawyPrzepisy wprowadzające Kodeks postepowania karnego, ustawy o świadku koronnym oraz ustawy o ochronie informacji niejawnych [Act of 10 January 2003 amending the law-The Code of Criminal Procedure, the law-Provisions implementing the Code of Criminal Procedure, the Crown Witness Act, and the act on the protection of classified information]. Journal of Laws No. 17, item 155.

Ustawa z dnia 16 listopada 2006 r. o zmianie ustawy-Kodeks karny oraz niektórych innych ustaw [Act of 16 November 2006 amending the act-The Penal Code and certain other acts]. Journal of Laws No. 226, item 1648.

Ustawa z dnia 27 września 2013 r. o zmianie ustawy-Kodeks postępowania karnego oraz niektórych innych ustaw [Act of 27 September 2013 amending the Act-The Code of Criminal Proceedings and certain other acts]. Journal of Laws of 2013, item 1247 as amended.

\section{CASE LAW}

Judgement of the Supreme Court of 13 December 2010, file ref. no. IV KK 294/10, OSNwSK of 2010, no. 1, item. 2498.

Judgement of the Supreme Court of 19 April 2011, file ref. no. II KK 285/10, LEX no. 795773.

Judgement of the Supreme Court of 17 May 2011, file ref. no. III KK 117/11, OSNKW of 2011, no. 9, item. 80 .

Judgement of the Supreme Court of 7 March 2012, file ref. no. II KK 30/12, Prokuratura i Prawo, insert 6 (2012), item 9.

Judgement of the Supreme Court of 10 June 2014, file ref. no. III KK 129/14, LEX no. 1475170.

Judgement of the Supreme Court of 16 October 2014, file ref. no. II KK 272/14, LEX no. 1539460.

Judgement of the Supreme Court of 30 March 2015, file ref. no. II KK 72/15, LEX no. 1659230.

\section{LITERATURE}

DudKA, Katarzyna, and Hanna PALuszkiewicz. Postępowanie karne. Warszawa: Wolters Kluwer, 2017. 
EICHSTAedT, Krzysztof. Postępowania szczególne $w$ polskim procesie karnym. Warszawa: Wydawnictwo LexisNexis, 2010.

EICHSTAEDT, Krzysztof. Komentarz do art. 500-501 k.p.k.. LEX 2018. Accessed July 16, 2018. https://sip. lex.pl/\#/commentary/587688318/567763.

Gaberle, Andrzej. Postępowania szczególne w kodeksie postępowania karnego z 1997 r. Kraków: Kantor Wydawniczy Zakamycze, 1998.

GRAJEWSKI, Jan. "Rozdział 53. Postępowanie nakazowe. Komentarz do art. 500 k.p.k.” In Kodeks postepowania karnego. Komentarz, by Jan GRAJEwSKI, Lech K. PAPRZYCKI, and Sławomir STEINBORN, Kodeks postępowania karnego, 2:219-43. Kraków: Kantor Wydawniczy Zakamycze, 2006

GRZEGORCZYK, Tomasz. Kodeks postępowania karnego. Komentarz. Warszawa: Wolters Kluwer, 2008.

KRUK, Ewa. "Postępowanie nakazowe.” In Postępowanie szczególne i odrębne w procesie karnym, edited by Katarzyna Dudka, 66-86. Warszawa: Wolters Kluwer, 2012.

Marszae, Kazimierz, Stanisław Stachowiak, and Kazimierz ZgryzeK. Proces karny. Katowice: Wydawnictwo Volumen, 2003.

SKoruPKA, Jerzy. "Rozdział II. Pojęcie procesu karnego. Przedmiot i podstawa procesu." In System prawa karnego procesowego. Zagadnienia ogólne, edited by Piotr Hofmański, 1/1: 109. Warszawa: Wydawnictwo LexisNexis, 2013.

SowIŃSKI, Piotr K. Uprawnienia składające się na prawo oskarżonego do obrony. Uwagi na tle czynności organów procesowych oraz oskarżonego. Rzeszów: Wydawnictwo Uniwersytetu Rzeszowskiego, 2012.

SteInborn, Sławomir. Komentarz do art. 95 k.p.k. LEX 2018. Accessed July 18, 2018. https://sip.lex.pl /\#\#/commentary/587696264/493704.

ŚwiATŁowsKI, Andrzej. "Rozdział XVI. Typowy i atypowy przebieg procesu karnego.” In System prawa karnego procesowego. Zagadnienia ogólne, edited by Piotr Hofmański, 1/2: 193-285. Warszawa: Wydawnictwo LexisNexis, 2013.

ŚwiATŁowsKI, Andrzej. Jedna czy wiele procedur karnych. Kraków: Arche, 2008.

Waltoś, Stanisław. Postępowania szczególne w procesie karnym. Postepowanie kodeksowe. Warszawa: Wydawnictwo Prawnicze, 1973.

Waltoś, Stanisław, and Piotr Hofmański. Proces karny. Zarys systemu. Warszawa: Wydawnictwo Wolters Kluwer, 2016.

\section{PENAL ORDER PROCEEDINGS \\ AS A MANIFESTATION OF PERMISSIBLE SIMPLIFICATION OF CERTAIN PROCEDURAL INSTITUTIONS}

\section{Summary}

Penal order proceedings are but one type of special procedure. They are characterised by a far-reaching reduction in formalism. The article discusses institutions which are characteristic for this type of proceedings, noting the admissibility of such solutions but also the dangers inherent in adjudication only on the basis of evidence collected by the public prosecutor. In addition, 
a detailed analysis of the positive and negative criteria for the use of penal order proceedings was presented.

Key words: ordinary proceedings; special proceedings; penal order proceedings; order; objection; formalism; positive and negative reasons.

Translated by Tomasz Patkowski

The preparation of the English version of Roczniki Nauk Prawnych (Annals of Iuridical Sciences) and its publication in electronic databases was financed under contract no. 836/PDUN/2018 from the resources of the Minister of Science and Higher Education for the popularization of science. 